\title{
DEVELOPMENT OF PINK DISEASE ON VARIOUS AGES OF Acacia crassicarpa CUNN EX. BENTH.
}

\author{
Rosa Suryantini ${ }^{1}$ \& Soelistijono ${ }^{2}$ \\ ${ }^{1}$ Faculty of Forestry, Universitas Tanjungpura, Indonesia \\ Jl. Imam Bonjol, Pontianak 78124 \\ ${ }^{2}$ Faculty of Agriculture, Universitas Tunas Pembangunan, Indonesia \\ Jl. Walanda Maramis No. 31 Nusukan, Surakarta 57135 \\ E-mail: asoerrosa@gmail.com
}

Manuscript received: 8 July 2020. Revision accepted: 28 August 2020.

\begin{abstract}
Development of pink disease on the various ages of Acacia crassicarpa Cunn Ex. Benth.. The increase in the value of pulp and paper exports in Indonesia is partly due to the development of industrial forest plantations of acacia on peatlands. Acacia crassicarpa grows well on peatlands with high productivity. However, the development of pink disease is a threat to the growth of $A$. crassicarpa, both in the nursery and in the field. This study aimed at examining the development of pink disease on the various ages of $A$. crassicarpa. The study was conducted using census method on plants at aged 4,24 and 42 months. Variables observed were symptoms, incidence, and severity of disease. Data were analyzed descriptively and regressively to understand the relationship between the incidence and severity of the disease and the age of the plant. The results showed that the symptoms that appearing at the seedling level were similar to those the sapling, poles and tree level. The presence of thin colonies of cobweb-like (cobweb stage), mycelia aggregation from the cobweb stage (pseudonodular stage), and the appearance of pustules and pink incrustation (teleomorph stage) were common symptom. However, disease incidence and severity were moderate at the seedling and mild at the saplings, poles and trees level. The incidence and severity of disease decreased with increasing age.
\end{abstract}

Key words: disease incidence, disease severity, pink disease, Upasia salmonicolor, woody plant

\section{INTRODUCTION}

Acacia is source of pulp and paper material that plays a role in the Indonesian economy. In 2017, the value of pulp and paper exports increased by $15.15 \%$ per year or by 7.26 billion USD/year (Direktorat Jendral Industri Agro, 2020). This large export value makes pulp and paper production as the biggest contributor to state revenues from the forestry sector besides oil and coal. The high pulp and paper production is supported by the presence of plantation forest. Acacia crassicarpa is one of the acacias grown in these plantation forest to supply pulp and material for paper.

A. crassicarpa had the highest productivity on peatlands among other acacias. It is therefore widely distributed in Kalimantan and Sumatra region. It requires six years for one crop rotation, considering its highest production at 4-5 years. Chemical properties and dimensions of wood fibers with quality I and II at 4-6 years, while the highest wood rendamen at years 4 (Suhartati et al., 2013).
Furthermore, the crop rotation of $A$. crassicarpa has changed, from 6 years in one crop rotation to 4-5 years in one crop rotation. It was due to the decline in wood consumption with increasing age so that the older the tree, the lower the consumption of wood, A. crassicarpa crop rotation should take 4-5 years (Akbar et al., 2019).

Recently, the growth of $A$. crassicarpa has been disturbed by cracked bark, broken twig and branch, and ultimately, plant death resulting in decreased production. Pink disease caused by Upasia salmonicolor (B. et Br.) Tjokr. or Corticium salmonicolor (B. et Br) (sin. Erythricium salmonicolor (B. et Br.) Burdsall, from the Basidiomycota phylum has been reported as one of the cause of this problem (Tjokrosoedarmo, 1997). Until 1994, the reports of diseases caused by fungi in A. crassicarpa were very few. A. crassicarpa was assumed to be resistant to fungal pathogens (Old et al., 1997), including U. salmonicolor. There have been no reports therefore of pink disease in A. crassicarpa. This study was important considering that the habitat of 
A. crassicarpa growing at high humidity and low light intensity area that trigger the development of the fungal diseases (Berlian \& Putra, 2019).

Some studies reported that pink disease was a minor disease, and did not cause death in aquilaria plants (Syazwan et al., 2019). Cost efficient control technique for this disease have not been identified yet (Asmaliyah \& Utami, 2009) because generally plants affected by pink disease were not considered a threat. Minor diseases can easily develop into major problems if not properly handled. U. salmonicolor has a wide host range in West Kalimantan including rubber, Eucalyptus, aquilaria and acacia which may allowed this condition to develop into a major disease. Therefore, this study on the development of pink disease in A. crassicarpa is necessary to plan appropriate and cost-efficient prevention strategies.

\section{MATERIALS AND METHODS}

Research Site. The study was conducted on AprilJune 2020 in the Plantation Forest area of PT Kalimantan Subur Permai, Lintang Batang Village, Kubu Raya Regency, West Kalimantan, at two sampling area (Figure 1).

Field Observations. The study was conducted using a survey method by observing each tree that had symptoms due to pink disease in age 4, 24 and 42 months. About 150 seedlings in nurseries aged 4 months were also evaluated. In the field, 1,666 trees/ha at 24 months and another 1,666 tress/ha at 42 months were surveyed. The trees were planted at spacing of $3 \times 2 \mathrm{~m}$ on 3 ha of land. The observed variables consisted of the disease symptoms, incidence and disease severity were observed variable.

Isolation and Identification. Isolation and identification of $U$. salmonicolor were done in the Silviculture Laboratory Faculty of Forestry Tanjungpura University after plant damage observation in the field. Colonies growing on infected branches (cut branches about 3 $\mathrm{cm})$ were cultured on potato dextrose agar (PDA) media, and incubated at room temperature for 5 days (Figure 2). The growing mycelia were re-cultured on PDA for 1 week to observe the macro-morphology of concentric circles, colour and air hypha. Microscopic observation was carried out directly on the mycelia that formed cobweb on stems and branches. Mycelia were placed on object glass and observed under microscope. The micro morphology of $U$. salmonicolor was observed based on the characteristic of spore, hypha and clamp connection (Akrofi et al., 2014).

Observation of Stem Tissue. The infected stem tissue was done by cutting the tissue lengthwise and dropping trypan blue under a microscope.

Data Analysis. The development of symptoms was descriptively analyzed. The data of crop damage were analyzed using the formula of disease incidence and severity based on the scores and the percentage of

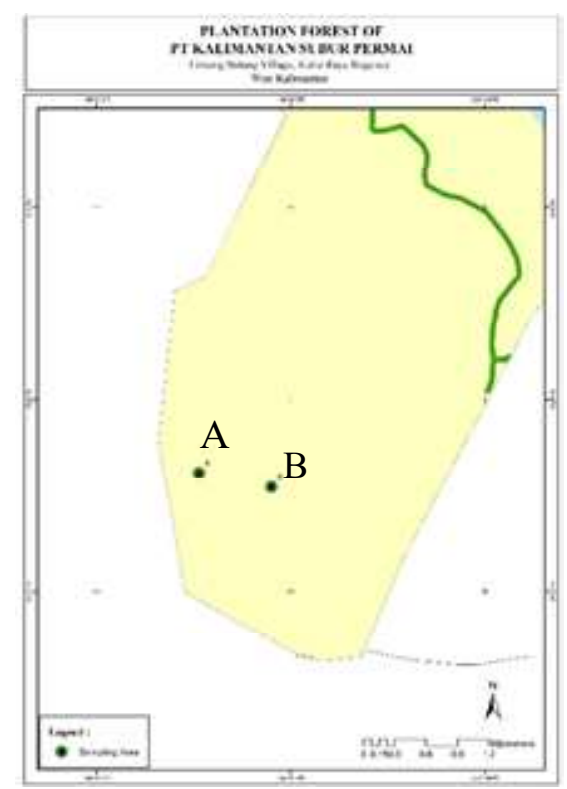

Figure 1. Plantation Forest of PT. Kalimantan Subur Permai, Lintang Batang Village, Kubu Raya Regency, West Kalimantan (A sampling area: LU $00^{\circ} 01^{\prime} 37.12^{\prime \prime}$, BT $109^{\circ} 41^{\prime} 31.81^{\prime \prime}$ and B sampling area: LU $00^{\circ} 01^{\prime}$ $32.54 "$, BT $\left.109^{\circ} 41^{\prime} 54.12^{\prime \prime}\right)$. 
infected or healthy plant parts due to pink disease by Griffin et al. (2003) (Table 1). The relationship between plant age and disease of incidence and severity was analyzed using linear regression. Disease of incidence was calculated using the following formula:

$$
\text { DI }=\frac{\mathrm{n}}{\mathrm{N}} \times 100 \%
$$

DI: disease incidence

$\mathrm{n}:$ number of infected plants

$\mathrm{N}$ : number of plants observed

Disease of severity was calculated using the following formula:

$$
\text { DS }=\frac{\sum_{\mathrm{i}=0\left(\mathrm{n}_{\mathrm{i}} \times \mathrm{v}_{\mathrm{i}}\right)}^{\mathrm{i}}}{\mathrm{N} \times \mathrm{V}} \times 100 \%
$$

DS: disease severity

$\mathrm{n}_{\mathrm{i}}$ : number of plants corresponding particular symptom scale

$\mathrm{v}_{\mathrm{i}}$ : value of certain symptoms score

$\mathrm{N}$ : number of plants observed

$\mathrm{V}$ : value of the highest severity score

\section{RESULTS AND DISCUSSION}

Results showed that the symptoms of pink disease in A. crassicarpa were similar to the symptoms of pink disease in sunan hazelnut plants (Florina et al., 2017; Old et al., 2003). Some of the specific symtomatic stages of this disease were the cobweb stage, characterized by the appearance of thin white, shiny and silky mycelium that then sporadically developed and expanded (Figure 3A \& B). According Akrofi et al. (2015), this stage appeared as a white layer to pink coloured on the surface of the stem or branch bark and was followed by the formation of pink to salmon colored pustules on any part of the infected stem or branch, namely the teleamorph stage (Figure $3 \mathrm{C}, \mathrm{D}$, and $\mathrm{E}$ ). Before the formation of pustule, the vegetative mycelia of the cobweb stage, formed aggregation. It was suggested as the pseudonodular stage (Figure 4B). The development of pink disease in A. crassicarpa is similar to the symptoms development in coffee and calliandra plant. However, not all of symptoms occurred in other plants infected by U. salmonicolor (Tjokrosoedarmo, 1997).

Pink disease in A. crassicarpa observed both in the base of the main stem and branches and twigs. This was indicated by the presence of pink to salmonencrustation would develop into creamy pustule on stems and branches that extending to all parts of the plant until dieback observed by death in the canopy, broken stems and brittle branches and twigs. This disease not only found on A. crassicarpa at the saplings, poles, and trees level, but it also observed in seedlings when the stems were woody (Figure 3E). U. salmonicolor infection could reach all tissues of heartwood and sapwood to the vascular tissue resulting in necrosis in the wood tissues (Figure 3F).

Based on observation of the colonies growing in the branch of $A$. crassicarpa, the conidia was hyalinecolored (Figure 4A). U. salmonicolor formed clam connection (Figure 4C) with the multinucleate hyaline hyphae (Figure 4D).

Table 1. Scores and the percentage of infected or healthy plant parts due to pink disease (Griffin et al., 2003)

\begin{tabular}{cl}
\hline Scores & The percentage of infected or healthy plant parts for each corresponding score \\
\hline 1 & Healthy plants or small colonies in branches \\
2 & Colonies on primary branches, canopy is still $75 \%$ \\
3 & Colonies on the main stem, cracked bark, infected canopy of $25-75 \%$ \\
4 & Colonies on the main stem, branches, and twigs, infected canopy of $25 \%$ \\
5 & Dead plants \\
\hline
\end{tabular}

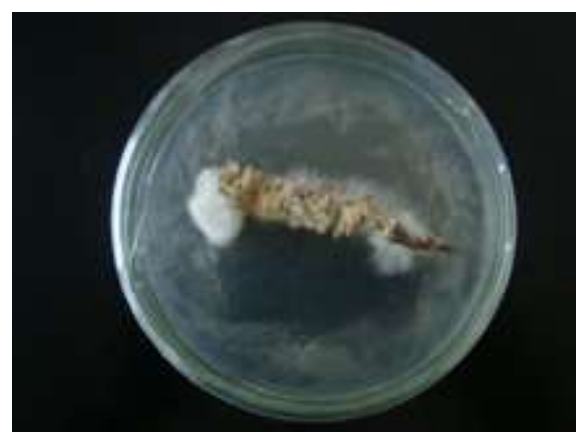

Figure 2. Colonies on branches cultured on PDA media for 7 days. 
Colonies growing on PDA for five days were white with clear concentric circles (Figure 4E). Conidia were also found on rubber rods (Florina et al., 2017). However, conidia or sporulation structures were not observed on the colonies growing on PDA (Kwarteng et al., 2018; Akrofi et al., 2015). This due to the formation of conidia in $U$. salmonicolor triggered by natural factors such as humidity, temperature, and light.

$U$. salmonicolor infection in A. crassicarpa caused damage with a disease incidence and severity of $26.67 \%$ and $26.67 \%, 13.96 \%$ and $13.38 \%$, as well as
$11.80 \%$ and $11.51 \%$ at 4 months, 24 months and 42 months age, respectively (Figure 5).

The regression analysis showed that the effect of plant age was very high on disease incidence and disease severity, i.e. R2 $=87.7 \%$ and $86.25 \%$, respectively (Figure 6). There was a negative correlation between plant age and disease incidence (the correlation equation was $y=-0.396 x+26.712$ ), as well as between plant age and disease severity (the correlation equation was $\mathrm{y}=-0.404 \mathrm{x}+26.61)$. This correlation showed that increasing age of plant reduced

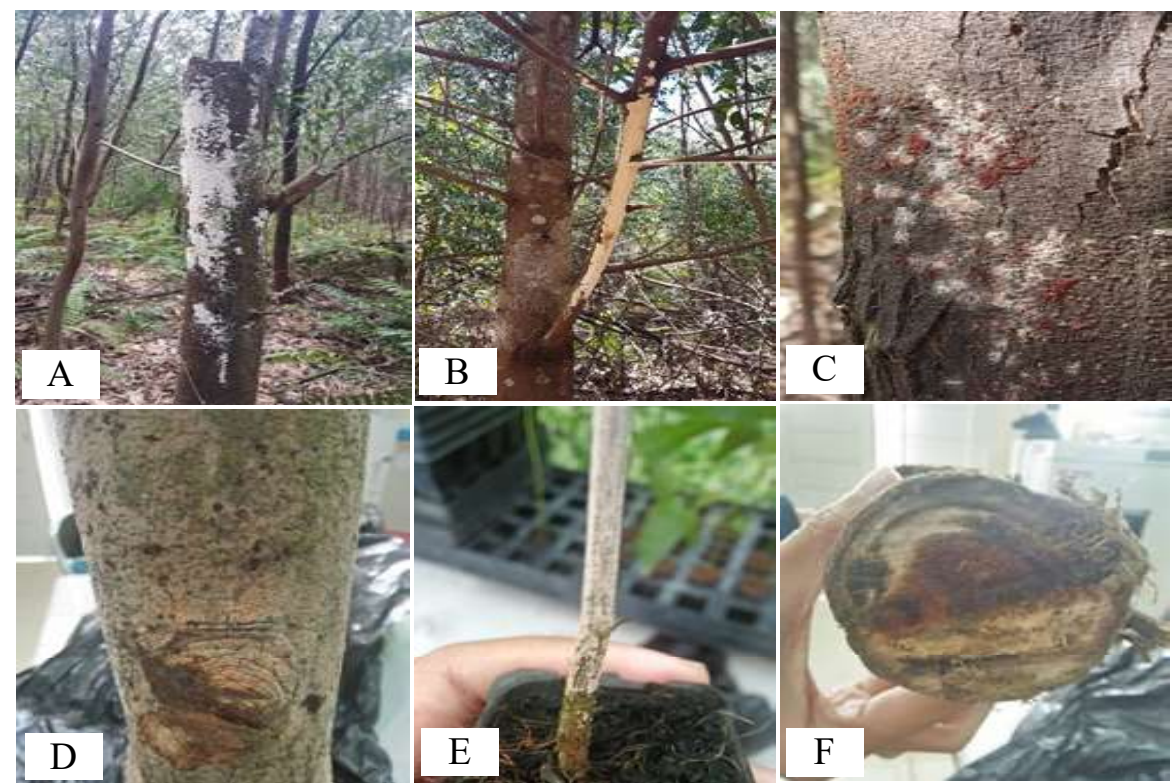

Figure 3. Development of symptoms of pink disease in A. crassicarpa trees. (A) Colony cobweb-like on stems; (B) Colonies on branches; (C) Orange-pink nodules or pustules; (D) Incrustation pink on stem; (E) Incrustation pink on seedlings 4 months; (F) Necrosis in wood tissue.

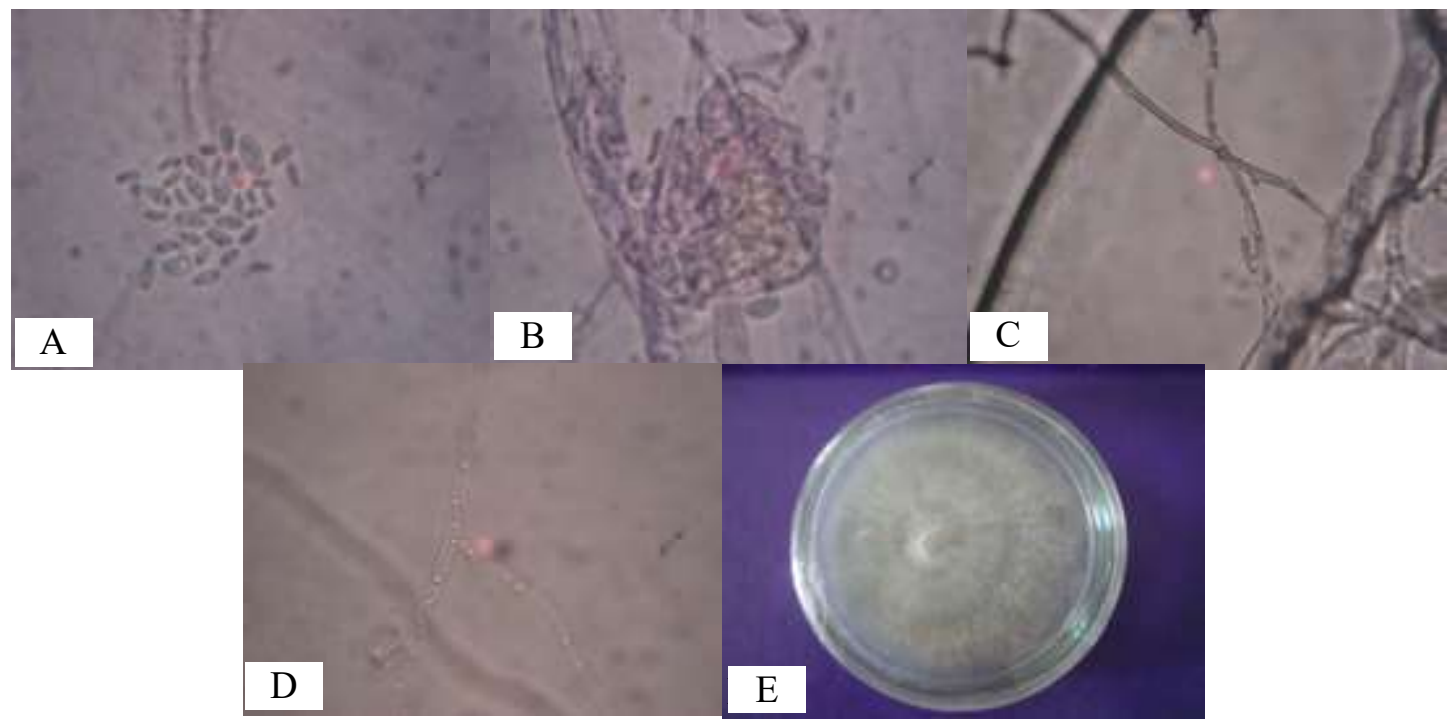

Figure 4. U. salmonicolor. (A) conidia (100× magnification); (B) pseudonodular stage $(100 \times$ magnification); (C) clamp connection (40× magnification); (D) multinucleated hyphae; (E) 5-day-old culture. 
the incidence and severity of disease. In other words, the decrease in pink disease was due to increased resistance as the plant increased in age.

Seedling pathogen such as Rhizoctonia solani is more deadly to the roots of plants at succulent period than fully grown plants. After seedlings were over five months, $R$. solani infection do not cause symptoms in plants (Suryantini et al., 2012). This is in contrast to the wood rot pathogens, where severity occurrs with an increase in stem diameter, such as Ganoderma spp. infected Acacia mangium (Suryantini \& Wulandari, 2018). As the wood rot pathogens degrade cellulose and

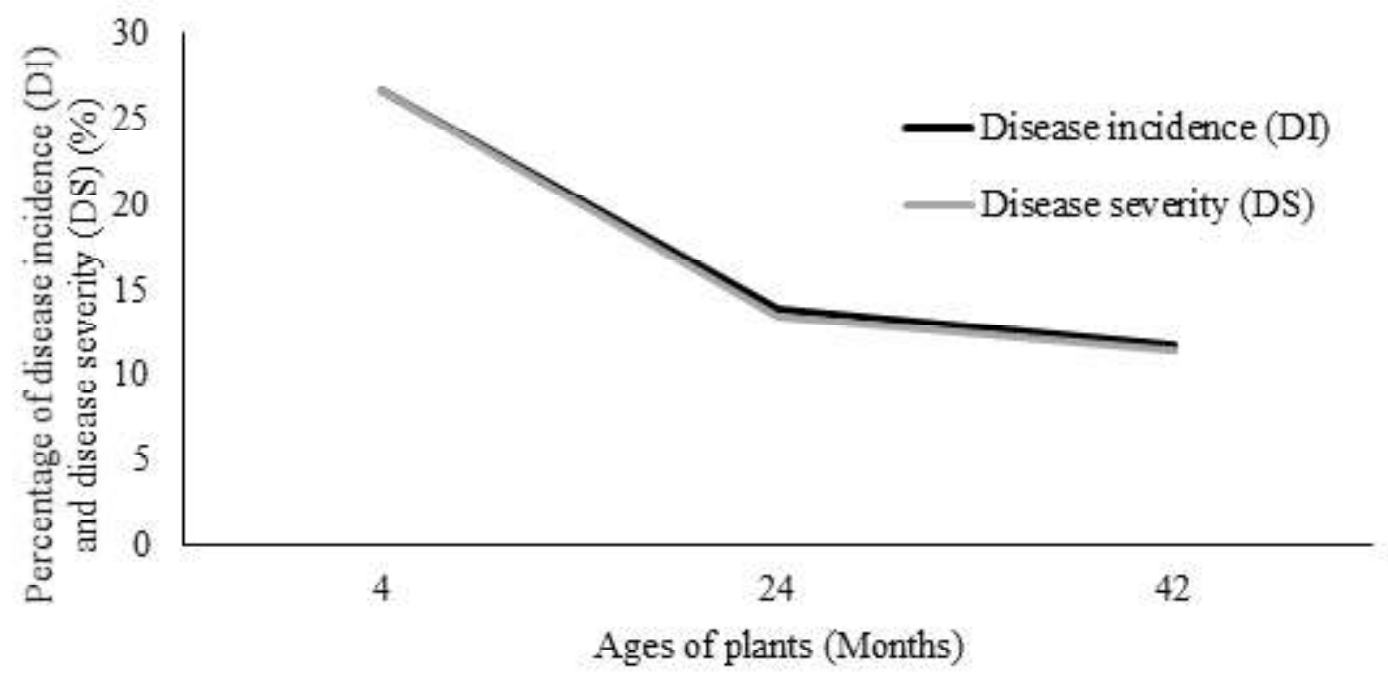

Figure 5. Disease incidence and severity of pink disease on various ages $A$. crassicarpa.
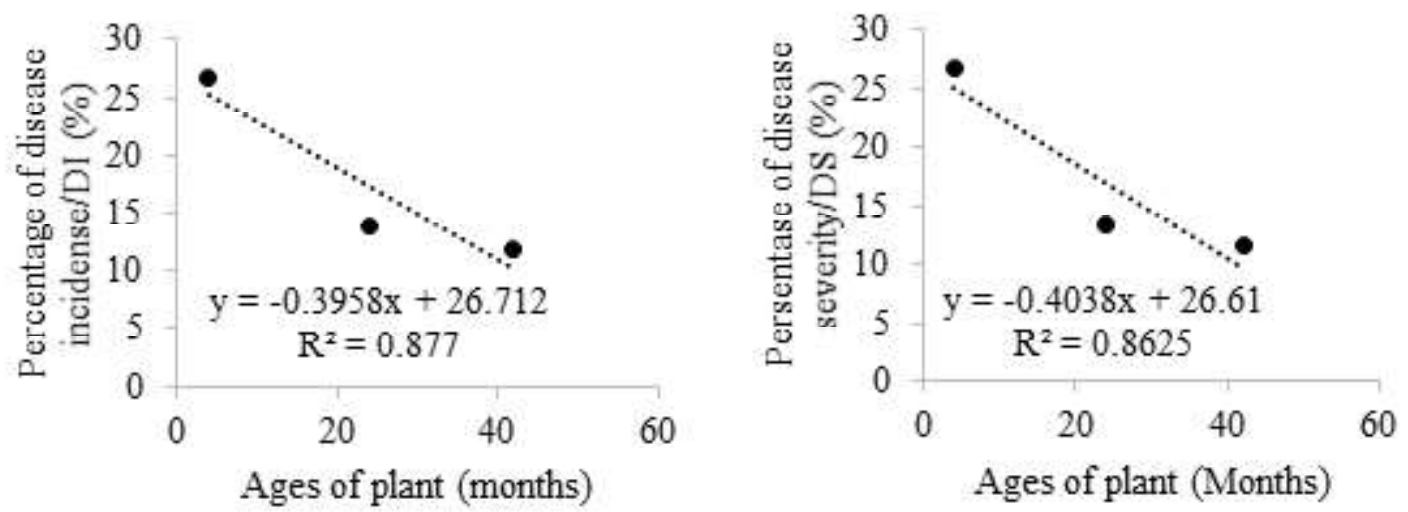

Figure 6. The relationship between the age of $A$. crassicarpa with pink disease.
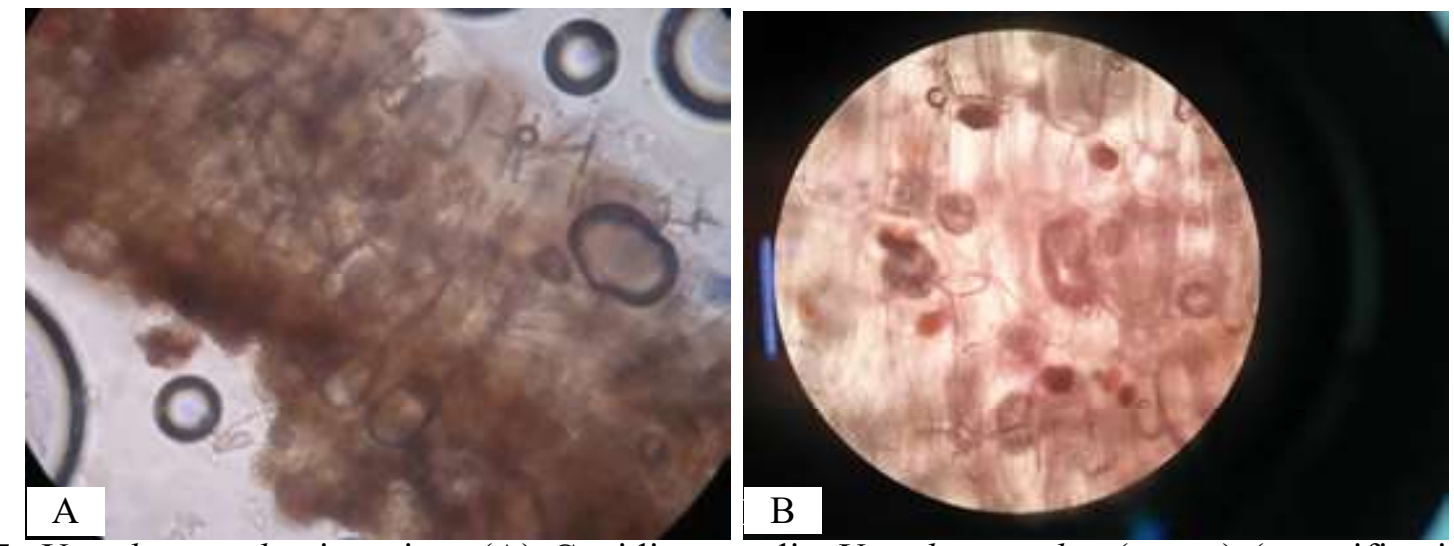

Figure 7. U. salmonicolor invasion. (A) Conidia mycelia U. salmonicolor (arrow) (magnification 40×); (B) tylose due to infection with U. salmonicolor on A. crassicarpa (100× magnification). 
lignin compounds that are increasingly available as plants age.

Upasia salmonicolor was also able to degrade cellulose and lignin based on its pathogenic presence in woody parts. It possibly penetrated through the lenticels and natural wounds, then its infection spread (Figure 7A). Physiologically, the growth of tissue in both stems and branches occurred both horizontally and vertically resulting in the broken bark would. When the skin was open, the cambium was drained so that resistance to air-borne pathogens such as U. salmonicolor decreased (Tran et al., 2017).

The negative correlation between the incidence and severity of pink disease with age of $A$. crassicarpa could be explained by the concept of CODIT (Compartmentalization of Decay in Trees). This concept explained the tree's resistance and susceptibility mechanism to the wood pathogenic fungi (Pouzoulet et al., 2014). One of these concepts was the existence of a circle of years which could centripetally limit the movement or spread of pathogens. Generally, cambium activity occurred in two directions, outward and inward. Inward growth would form darker-colored wood, composing of dead or inactive cells. Outward growth formed sapwood, consisting of active and light colored cells. The changed of sapwood into terrace wood was followed by the production of extractive substances, containing polyphenols. This compound could clog part or all of the plant tissue. Haroen \& Dimyati (2006) explained the higher extractive chemical components in acacia. The blockage due to U. salmonicolor infection stimulated the formation of extractive substances at higher concentrations. The polyphenol content of these extractive compounds was possible toxic to pathogens. Cambium activity would occur every year so that the circle of years would clearly be visible. Increasing ages of plant would add more circle of years on the stem so it could inhibit the spread of pathogens in plant tissue. Some of these extractive substances were produced as a response to plant defenses. It would stop if tylose was formed (Subramaniam \& Ramaswamy, 1987). Phenols would fill tylose (Figure 7B) and it would inhibit the development of pathogens in plant tissue. Tylose in the vessels can also block the nutrient transportation, that may be disrupt distribution of food substances, xylem collapse and death in the canopy (Kitin et al., 2010). Tylose itself is the response of plants, the which are inductively formed much ahead of pathogen infection. These responses represent defense signal pathway mediated by plant recognition receptors, phytohormones, other forms of resistance (Dou \& Zhou, 2012).

\section{CONCLUSION}

The symptom of pink disease on $A$. crassicarpa consisted of three stadia namely cobweb, pseudonoduar and teleomorph. The pink disease was observed in seedlings, saplings, poles and in stem of woody mature plants. However disease severity and disease incidence were declined along the increasing age of the plant.

\section{ACKNOWLEDGMENTS}

This research was funded by DIPA of Universitas Tanjungpura 2020 No. SP. DIPA 023.17.2677517/2020 dated 27 December 2019.

\section{REFERENCES}

Akbar OT, Aprianis Y, \& Ruspandi. 2019. Pulp and paper raw material characteristics comparison of 1 to 4 Krasikarpa (Acacia crassicarpa) A. Cunn. $J$. Penelit. Has. Hutan. 37(2): 93-104.

Akrofi AY, Amoako-Atta I, Assuah M, \& Kumi-Asare E. 2014. Pink disease caused by Erythricium salmonicolor (Berk. \& Broome) Burdsall: an epidemiological assessment of its potential effect on cocoa production in Ghana. J. Plant. Pathol. Microb. 5(1): 215.

Asmaliyah \& Utami S. 2009. Penyakit dan cara pengendaliannya pada beberapa tanaman lokal. In: Rostiwaty T, Effendi R, Bustomi S, \& Wibowo A (Eds.). Prosiding Seminar Hasil-Hasil Penelitian Balai Penelitian Kehutanan, Mengenal Teknik Budidaya Jenis-Jenis Pohon Lokal Sumsel dan Upaya Pengembangannya. pp. 179-187. Balai Penelitian dan Pengembangan Kehutanan, Palembang.

Berlian I \& Putra RC. 2019. Penyakit jamur upas (Corticium salmonicolor) di perkebunan karet dengan faktor pembatas berupa genangan. In: Subandi M \& Frasetya B (Eds.). Prosiding Seminar Nasional Agroteknologi. Jurusan Agroteknologi Universitas Islam Negeri Sunan Gunung Djati Bandung. pp. 291-298. Pusat Penelitian dan Penerbitan UIN SGD Bandung, Bandung.

Direktorat Jendral Industri Agro. 2020. Industri pulp dan kertas Indonesia. http:// agro.kemenperin.go.id. Accessed on July 2020. 
Dou D \& Zhou JM. 2012. Phytopathogen effectors subverting host immunity: different foes, similar battleground. Cell Host Microbe. 12(4): 484-495.

Florina D, Wahyuno D, \& Siswanto. 2017. Kepekaan Erythricium salmonicolor penyebab penyakit jamur upas pada kemiri sunan terhadap suhu, cahaya, dan fungisida. J. Fitopatol. Indones. 13(2): 35-42.

Griffin JM, Lovett GM, Arthur MA, \& Weathers KC. 2003. The distribution and severity of beech bark disease in the Catskill Mountains, NY. Can. J. For. Res. 33(9): 1754-1760.

Haroen WK \& Dimyati F. 2006. Sifat kayu tarik, teras dan gubal Acacia mangium terhadap karakteristik pulp. J. Sel. 41(1): 1-7.

Kitin P, Voelker SL, Meinzer FC, Beeckman H, Strauss SH, \& Lachenbruch B. 2010. Tyloses and phenolic deposits in xylem vessels impede water transport in low-lignin transgenic poplars: a study by cryo-fluorescence microscopy. Plant Physiol. 154(2): 887-898.

Kwarteng GF, Cornelius E, Acquah KK, \& Asare EK. 2018. Morphological and molecular identification of the fungus associated with pink disease of cocoa (Theobroma cacao L) in the Eastern Region of Ghana. IJPR. 1(1): 1-8.

Old KM, Wingfield MJ, \& Yuan ZQ. 2003. A Manual of Diseases of Eucalypts in South-East Asia. Center for International Forestry Research, Bogor.

Old KM, Hood IA, \& Yuan ZQ. 1997. Diseases of tropical acacias in Northern Queensland. In: Old KM, See LS, \& Sharma JK (Eds.). Proceedings of an International Workshop Diseases of Tropical Acacias. pp. 1-22. Center for International Forestry Research, Jakarta.
Pouzoulet J, Pivovaroff AL, Santiago LS, \& Rolshausen PE. 2014. Can vessel dimension explain tolerance toward fungal vascular wilt diseases in woody plants? Lessons from Dutch elm disease and esca disease in grapevine. Front. Plant Sci. 5(253): $1-11$.

Suhartati, Aprianis Y, Pribadi A, \& Rochmayanto Y. 2013. Kajian dampak penurunan daur tanaman Acacia crassicarpa A. Cunn terhadap nilai produksi dan sosial. Jurnal Penelitian Hutan Tanaman. 10(2): 109-118.

Subramaniam SV \& Ramaswamy V. 1987. Histopathological observations on pink disease of eucalyptus. Curr. Sci. 56(20): 1042-1044.

Suryantini R, Priyatmojo A, Widyastuti SM, \& Kasiamdari RS. 2012. Hypovirulent binucleate Rhizoctonia as biocontrol agent of Rhizoctonia solani in tusam seedling (Pinus merkusii). Jurnal Budidaya Pertanian 8(1): 27-30.

Suryantini R \& Wulandari RS. 2018. Diversity of Ganoderma pathogen in Pontianak, West Kalimantan: characteristics, virulence and ability to infect Acacia mangium seedlings. Biodiversitas 19(2): 465-471.

Syazwan SA, Lee SY, Ong SP, \& Mohamed R. 2019. Damaging insect pests and diseases and their threats to agarwood tree plantations. Sains Malays. 48(3): 497-507.

Tjokrosoedarmo AH. 1997. Life cycle of pink fungus (Upasia salmonicolor) in Java. JPTI. 3(2): 6166.

Tran TT, Glen M, Beadle C, Ratkowsky D, \& Mohammed C. 2019. Wood-rotting basidiomycetes are a minor component of fungal communities associated with Acacia hybrid trees grown for sawlogs in South Vietnam. Forest Pathol. 49(2): e12498. 